\title{
Studies of method of conserving grass herbage and frequency of feeding in cattle
}

\author{
1. Voluntary feed intake, digestion and rate of passage \\ BY L. R. L. THIAGO*, M. GILL† AND M. S. DHANOA \\ AFRC Institute for Grassland and Animal Production, Hurley, Maidenhead, Berkshire SL6 5LR
}

(Received 4 October 1990 - Accepted 19 June 1991)

\begin{abstract}
The effect of method of conserving grass herbage and the frequency of feeding on digestion in and passage from the rumen was studied in growing cattle. A single sward of perennial ryegrass (Lolium perenne cv. Endura) was cut on $1 \mathrm{~d}$ and conserved as silage or hay. These forages were offered as the only feed to twelve rumen-cannulated Friesian steers (average initial live weight (LW) $128 \mathrm{~kg}$ ) either at a restricted level of intake (20 g dry matter (DM)/kg LW; Expt 1) or ad lib. (Expt 2). In Expt 1 the forages were offered either once or eight times daily. When fed once or eight times daily, in vivo digestibility of DM was very similar for hay and silage (0-771 and 0.783 respectively), while the fractional rate of digestion measured by incubation in Dacron bags was significantly $(P<0.05)$ higher for silage (0.069) than hay $(0.057)$. The rate of passage of mordanted feed out of the rumen was significantly $(P<0.01)$ faster for silage when determined from concentrations of marker in the rumen $(0.034 \mathrm{v.0028} / \mathrm{h})$. The volume of liquid in the rumen was lower $(P<0.01)$ for animals consuming silage $(27.51)$ compared with hay $(37 \cdot 11)$, while the fractional rate of passage of liquid from the rumen was higher $(0.141 v .0 .098 / \mathrm{h}$, $P<0.05)$. The volume of liquid in the rumen was also lower $(P<0.05)$ in steers offered feed eight times daily (29.5 I), compared with once daily (35.1 I), but frequency of feeding had no significant effect either on total digestibility or on rate of digestion in the rumen. The ad lib. intake of silage was significantly $(P<0.01)$ lower than that of hay $(4.53 v .516 \mathrm{~kg} \mathrm{DM} / \mathrm{d})$ in Expt 2.
\end{abstract}

Grass herbage conservation: Feeding frequency: Rumen digestion: Voluntary intake: Steer

Conservation of grass as hay or silage alters the chemical composition of the herbage with consequent effects on digestion, utilization and voluntary intake. With hay these changes are characterized by oxidation of the water-soluble carbohydrates (WSCHO) and enzymic breakdown of the protein (Sullivan, 1973), while during ensiling the WSCHO are converted to organic acids and the protein to non-protein-nitrogen (McDonald \& Edwards, 1976). The effect on voluntary intake is that silage is frequently consumed to a lesser extent than the corresponding dried (Murdoch \& Rook, 1963; Campling 1966) or fresh (Demarquilly, 1973) herbage of similar digestibility. End-products of fermentation, both in the silo and in the rumen, have been implicated in this depression (e.g. Clancy et al. 1977).

In contrast to silage, the voluntary intake of hay is thought to be predominantly restricted by the amount of digesta in the reticulo-rumen, i.e. physical control (e.g. Freer \& Campling, 1963). Relief of this distension results from the combined processes of digestion and passage, but there have been few studies comparing the digestion and passage of hay and silage harvested from the same sward. Thus, the aim of the first experiment

* Present address: EMBRAPA/CNPGC, Cx. Postal 154, 79.100, Campo Grande, MS, Brazil.

$\dagger$ Present address: Natural Resources Institute, Central Avenue, Chatham Maritime, Chatham, Kent ME4 4TB. 
reported here was to study digestion in, and passage from, the rumen of cattle consuming hay or silage made from the same herbage. The consequent effects of these processes on rumen fill is considered in a subsequent paper. The voluntary intake of the two forages was measured in a second experiment and is also reported here. Preliminary results of some of the present work have been reported (Prates et al. 1986).

\section{EXPERIMENTAL}

Dietary treatments

The diets in both experiments consisted of hay and silage made from a single sward of perennial ryegrass (Lolium perenne cv. Endura) cut on the 8 June 1984. For hay, the grass was cut with a mower-conditioner, dried in the field, baled and stored in a barn. It was chopped into $30-50 \mathrm{~cm}$ lengths before feeding. The grass for silage was harvested with a precision-chop forage harvester and ensiled in a clamp silo after treatment with formic acid (3.51 ADD-F/tonne fresh material).

\section{Animals and design}

In Expt 1, twelve Friesian steers initially 4 months of age (average initial live weight (LW) $128 \mathrm{~kg}$ ) were fitted with rumen cannulas of $80 \mathrm{~mm}$ i.d. (University of Sydney, Australia). During the experiment they were kept in metabolism crates under continuous lighting and with free access to water and mineral blocks. The steers were offered forage as the only feed, either once daily ( 09.00 hours) or in eight equal portions at three-hourly intervals by means of a continuous-belt feeder (Collingwood Conveyor Equipment, Ware, Herts). The twelve steers were randomly allocated to the four dietary treatments in a two-period cross-over design, changing diets within feeding frequency. Each period lasted 6 weeks and consisted of a 2 -week adaptation period followed by 4 weeks of measurement. Animals were weighed at the beginning of week 2 and week 4 and these $L W$ were used to adjust the daily amount offered to $20 \mathrm{~g}$ dry matter (DM) $/ \mathrm{kg} \mathrm{LW}$.

In Expt 2, six of these steers (average initial $\mathrm{LW} 173 \mathrm{~kg}$ ) were housed in individual pens, also under continuous lighting and with free access to water and mineral blocks. The six steers were randomly allocated to hay or silage for the first period of $24 \mathrm{~d}$, the first $14 \mathrm{~d}$ being for adaptation to diet, the second $10 \mathrm{~d}$ for recording intake; diets were then changed over between animals, and the same procedure repeated for the second period. The forages were offered twice daily ( 09.00 and 15.30 hours) to give a total amount $100-150 \mathrm{~g} / \mathrm{kg}$ in excess of the previous day's consumption, to estimate voluntary intake.

\section{Expt 1. Experimental procedure}

\section{Digestibility}

Apparent digestibility coefficients were determined by total collection of faeces over the first $7 \mathrm{~d}$ of each measurement period. The faeces produced were allowed to accumulate on trays (lined with plastic sheets) beneath the metabolism crates. The faeces were removed and weighed once daily, frozen and bulked over the $7 \mathrm{~d}$ period for subsequent analysis.

\section{Rumen fermentation}

On day 6 of the faecal collection, rumen fluid samples were taken using a vacuum fluid extractor. Samples $(20 \mathrm{ml})$ were taken at 08.30, 09.30, 10.00, 10.30, 11.00, 12.00, 14.00, $16.00,18.00,21.00$ and 24.00 hours. The $\mathrm{pH}$ was measured immediately and the samples were then acidified with concentrated sulphuric acid and stored frozen before analysis for ammonia and volatile fatty acid (VFA) concentration. 
Degradability

During the second week of the measurement period, the degradability of the forages was determined by incubation of portions of the fresh hay and silage in Dacron bags (pore size $45 \mu \mathrm{m}$, size $170 \times 70 \mathrm{~mm}$ ) suspended in the rumen of the experimental steers for $1,2,3,6$, $9,12,24,48,72$ and $96 \mathrm{~h}$.

The forages were chopped manually into $10 \mathrm{~mm}$ long pieces before weighing approximately $6 \mathrm{~g}$ hay or $25 \mathrm{~g}$ silage (i.e. approximately $5 \mathrm{~g} \mathrm{DM}$ ) into the bags. The bags were then soaked in warm water for $10 \mathrm{~min}$ before suspending them in the rumen of steers offered the same diet as that being tested. One bag per animal was used as a zero time control. Ten bags were inserted into each animal, attached to a $350 \mathrm{~g}$ weight to maintain the bags in the ventral rumen. After removal, the bags were immediately placed in cold water and then washed under running tap water until the washings were clear. The bags plus contents were dried at $55^{\circ}$ until they reached constant weight, and the residues were analysed for DM and neutral-detergent fibre (NDF).

\section{Microbial activity}

In vitro gas production of samples of rumen digesta was determined as an estimate of microbial activity. Samples (13.5 g fresh weight) of whole, mixed digesta were taken just before fresh feed was offered, half-way through the first meal, at the end of the first meal and at 6,16 and $20 \mathrm{~h}$ after feeding in animals receiving feed once daily, and at 09.30,11.30, $13.30,21.30,23.30$ and 01.30 hours in animals receiving feed eight times daily. The samples taken were a portion of the total digesta which was removed for measurement of rumen fill at these times (Thiago et al. 1992). The samples were incubated in flasks in a water-bath at $39^{\circ}$ under anaerobic conditions and the gas produced was measured by displacement of liquid from a $25 \mathrm{ml}$ pipette submerged in a bath containing hydrochloric acid $(10 \mathrm{ml} / \mathrm{l})$. Recordings of the volume displaced were made at $10 \mathrm{~min}$ intervals over a total of $90 \mathrm{~min}$.

\section{Liquid passage rate}

On the first day of the in vivo digestibility trial, $360 \mathrm{mg}$ cobalt as CoEDTA (Uden et al. 1980) dissolved in $100 \mathrm{ml}$ distilled water was injected by a $50 \mathrm{ml}$ syringe into a large number of sites throughout the rumen immediately before feeding. Starting from $3 \mathrm{~h}$ after insertion of the marker, samples of rumen fluid $(30 \mathrm{ml})$ were withdrawn at $3 \mathrm{~h}$ intervals until $33 \mathrm{~h}$ after dosing, and stored frozen.

\section{Particulate passage rate}

On the first day of the in vivo digestibility trial, portions (about $100 \mathrm{~g}$ dry weight) of chromium-mordanted hay or silage (Uden et al. 1980) were inserted into the rumen immediately before feeding. Samples were collected at frequent intervals for up to 5 and $6 \mathrm{~d}$ after insertion of the marker from rumen and faeces respectively. Grab samples from the lower, mid and upper layers of rumen digesta, to give an overall sample of $15-20 \mathrm{~g}$ dry weight, were taken at $3 \mathrm{~h}$ intervals until $33 \mathrm{~h}$ for the first $2 \mathrm{~d}$ after dosing, then three times daily for the next $3 \mathrm{~d}$. Faecal sampling started $12 \mathrm{~h}$ after dosing and continued at $3 \mathrm{~h}$ intervals until $33 \mathrm{~h}$ after dosing, then three times daily for the next $4 \mathrm{~d}$. These samples were dried at $100^{\circ}$ and analysed for concentration of $\mathrm{Cr}$.

\section{Chemical analysis}

Fresh silage was used for determining DM, total N, ammonia and organic acids, whilst other silage analyses, and hay, faeces and digesta analyses were conducted on freeze-dried samples. 
DM contents of hay, faeces and digesta samples were determined by drying samples to constant weight in a forced-draught oven at $100^{\circ}(24 \mathrm{~h})$. Silage DM was determined by toluene distillation (Dewar \& McDonald, 1961). Ash was measured by igniting samples in a muffle furnace at $550^{\circ}$ overnight; acid-detergent fibre (ADF) was measured as described by Van Soest (1963) and NDF as described by Van Soest \& Wine (1967) with modifications reported by Van Soest \& Robertson (1980). WSCHO content was determined according to McDonald \& Henderson (1964), total $\mathrm{N}$ by a Kjeldahl digestion procedure, and an automated colorimetric procedure with alkaline phenate hypochlorite was used to measure ammonia concentration (Gehrke et al. 1968). Silage fermentation acids were extracted with $0.6 \mathrm{M}$-sulphuric acid, as were VFA in centrifuged, acidified rumen fluid, and analysed using a Hewlett-Packard model 5700A gas-liquid chromatograph employing a column fitted with chromosorb 101 at $160^{\circ}$.

The concentration of $\mathrm{Co}$ in rumen fluid and $\mathrm{Cr}$ in rumen digesta and faeces were determined by atomic absorption spectrometry (Varian Techtron Pty Ltd, Australia), using a nitrous oxide acetylene flame. For Co analysis, samples were thawed, acidified (five to six drops of concentrated sulphuric acid) and centrifuged at $3500 \mathrm{rev} . / \mathrm{min}$ for $10 \mathrm{~min}$. Co was measured in the supernatant fraction using the standard procedure given by Varian Techtron. Rumen digesta and faeces samples were ashed overnight at $550^{\circ}$ and $\mathrm{Cr}$ extracted by wet digestion as described by Christian \& Coup (1954).

\section{Calculations and statistical analysis}

\section{Degradability curves}

The fractional rates of degradation were estimated by fitting the values (Dhanoa, 1988) for percentage disappearance of DM or NDF with time to the equation proposed by McDonald (1981):

$$
y=a+b\left(1-e^{-k_{d^{t}} t}\right), t>t_{\mathrm{o}}
$$

where $y$ is DM or NDF disappearance from the bag, $a$ is loss at time, $t=0, b$ is potentially degradable insoluble material, $k_{a}$ is fractional rate of degradation of DM or $\mathrm{NDF}$ of fraction $b, t$ is time of incubation, $t_{\mathrm{o}}$ is lag time.

\section{Passage of liquid}

The rumen liquid volume, passage and outflow rates were calculated as proposed by Warner \& Stacy (1968).

\section{Particulate passage}

Fractional rates of passage were calculated from the $\mathrm{Cr}$ concentration in rumen digesta by regression of the logarithmic values of the decrease in Cr concentration v. time. Estimation of passage rates based on excretion curves of marker in the faeces were calculated by applying the models of Grovum \& Williams (1973) and Dhanoa et al. (1985).

\section{Statistical analysis}

Analysis of variance was conducted using the GENSTAT (1977) statistical package. The maximum likelihood program (MLP; Ross, 1980) was used in the estimation of rates of DM and NDF degradation in situ and of rates of passage; this program estimates nonlinear parameters using direct iterative methods. 
Table 1. Chemical composition $(\mathrm{g} / \mathrm{kg}$ dry matter) of the ryegrass (Lolium perenne $\mathrm{c} v$. Endura) hay $(H)$ and silage $(S)^{*}$

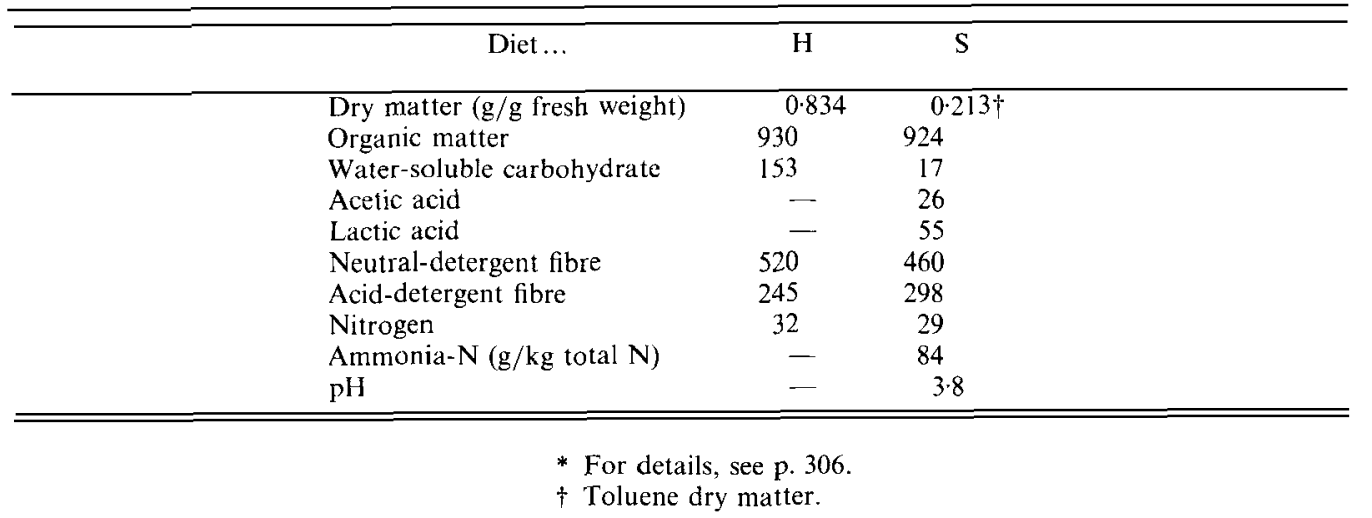

RESULTS

Feed composition

The silage had good fermentation characteristics, as indicated by the high lactic acid and low $\mathrm{pH}$, ammonia- $\mathrm{N}$ and acetic acid concentrations (Table 1). Fermentation in the silo considerably reduced the fraction of WSCHO in silage $(17 \mathrm{~g} / \mathrm{kg}$ DM) compared with hay $(153 \mathrm{~g} / \mathrm{kg} \mathrm{DM})$. The content of NDF in the hay was higher and that of ADF lower than in the silage.

\section{Digestibility}

For animals fed once daily, no differences in digestibility of DM or organic matter (OM) were observed between hay and silage. The digestibility of the NDF was higher $(P<0.01)$ and ADF lower $(P<0.05)$ for hay than silage (Table 2$)$. When these same diets were fed eight times daily, the digestibility coefficients for DM, OM and ADF were significantly higher for silage than hay, although no difference was found for the NDF fraction.

\section{Rates of digestion}

Silage had a significantly $(P<0.001)$ higher fraction of water-soluble DM than hay $(0 \cdot 40$ v. 0.26$)$, and a significantly $(P<0.01)$ lower amount of potentially digestible DM $(a+b)$ (Table 3 ). This was presumably due to the loss of soluble material in the silage effluent since the amount of potentially digestible NDF did not differ between silage and hay. Digestion rate $\left(k_{t} / \mathrm{h}\right)$ of the water-insoluble nutrients was greater for silage than hay only for the DM content, although the lag time before the start of digestion was longer for hay than silage with both the DM and NDF. Feeding frequency had no effect on any of the indices measured.

\section{Rumen fermentation}

Feeding once daily was characterized by a rapid increase in total VFA immediately after offering hay or silage. Maximum values were reached 3 and $5 \mathrm{~h}$ after feeding silage and hay respectively (Fig. 1(a)). The $\mathrm{pH}$ of rumen fluid also decreased rapidly after feeding, with the values for animals eating silage being significantly lower than for those eating hay within the first $1.5 \mathrm{~h}$ after feeding (Fig. 2). Rumen ammonia concentration before feeding was 
Table 2. Apparent in vivo digestibility coefficients of dry matter (DM), organic matter $(O M)$, neutral-detergent fibre $(N D F)$ and acid-detergent fibre $(A D F)$ in steers offered 20 g ryegrass (Lolium perenne $c v$. Endura) hay $(H)$ or silage $(S)$ dry matter $/ \mathrm{kg}$ live weight, once $(1 \times)$ or eight times $(8 \times)$ daily $\dagger$

\begin{tabular}{|c|c|c|c|c|c|}
\hline \multirow{2}{*}{$\begin{array}{l}\text { Feeding } \\
\text { frequency }\end{array}$} & & \multirow[b]{2}{*}{ Hay } & \multirow[b]{2}{*}{ Silage } & \multirow[b]{2}{*}{ SEM } & \multirow{2}{*}{$\begin{array}{c}\begin{array}{c}\text { Statistical } \\
\text { significance }\end{array} \\
\text { H v.S }\end{array}$} \\
\hline & & & & & \\
\hline $1 \times$ & $\mathrm{DM}$ & 0.778 & 0.779 & 0.0044 & NS \\
\hline & $\mathrm{OM}$ & 0.790 & 0.794 & 0.0037 & NS \\
\hline & NDF & 0.847 & 0.826 & 0.0027 & $* *$ \\
\hline & $\mathrm{ADF}$ & 0.827 & 0.851 & 0.0038 & * \\
\hline $8 x$ & DM & 0.764 & 0.787 & 0.0052 & $*$ \\
\hline & OM & 0.778 & $0 \cdot 801$ & 0.0043 & * \\
\hline & NDF & 0.832 & 0.830 & 0.0039 & NS \\
\hline & $\mathrm{ADF}$ & 0.821 & 0.858 & 0.0029 & $* * *$ \\
\hline
\end{tabular}

NS, not significant $(P>0.05)$.

* $P<0.05,{ }^{* *} P<0.01,{ }^{* * *} P<0.001$.

+ For details of diets and procedures, see p. 306 and Table 1.

$\ddagger 4 \mathrm{df}$.

Table 3. Estimates $\dagger$ of the potentially digestible fraction $(\mathrm{a}+\mathrm{b})$, fractional rate of digestion $\left(\mathrm{k}_{\mathrm{d}}, h\right)$; and lag time $\left(\mathrm{t}_{o}, h\right)$ of dry matter $(D M)$ and neutral-detergent fibre $(N D F)$ measured as in situ disappearance from Dacron bags suspended in the rumen of steers for intervals up to $96 \mathrm{~h}$

\begin{tabular}{|c|c|c|c|c|c|c|c|c|}
\hline \multirow[b]{2}{*}{ Treatment $\ddagger \ldots$} & \multicolumn{2}{|c|}{$1 \times$} & \multicolumn{2}{|c|}{$8 x$} & \multirow[b]{2}{*}{ SEM $\$$} & \multicolumn{2}{|c|}{$\begin{array}{c}\text { Statistical } \\
\text { significance }\end{array}$} & \multirow[b]{2}{*}{ Interactior } \\
\hline & $\mathrm{H}$ & $\mathrm{S}$ & $\mathrm{H}$ & $\mathrm{S}$ & & $H$ v. S & $1 \times$ v. $8 \times$ & \\
\hline \multicolumn{9}{|l|}{$\overline{\mathrm{DM}}$} \\
\hline$a$ & $26 \cdot 2$ & $38 \cdot 8$ & $25 \cdot 8$ & $41 \cdot 1$ & 0.67 & $* * *$ & NS & NS \\
\hline$a+b$ & 0.928 & 0.918 & 0.938 & 0.915 & 0.43 & $* *$ & NS & NS \\
\hline$k_{d}$ & 0.057 & 0.062 & $0 \cdot 056$ & 0.076 & 0.0046 & * & NS & NS \\
\hline$t_{0}$ & $3 \cdot 1$ & $0 \cdot 3$ & $2 \cdot 6$ & 1.9 & 0.49 & $* *$ & NS & NS \\
\hline \multicolumn{9}{|l|}{ NDF } \\
\hline$a+b$ & 0.892 & 0.886 & 0.893 & 0.878 & 0.64 & NS & NS & NS \\
\hline$k_{d}$ & 0.059 & 0.053 & 0.061 & 0.065 & 0.0038 & NS & NS & NS \\
\hline$t_{0}$ & $4 \cdot 2$ & $0 \cdot 8$ & $4 \cdot 2$ & $1 \cdot 3$ & $0 \cdot 60$ & $* * *$ & NS & NS \\
\hline
\end{tabular}

$1 \times$. Feed offered once daily; $8 \times$, feed offered eight times daily; H, ryegrass (Lolium perenne cv. Endura) hay;

$\mathrm{S}$, ryegrass silage: NS, not significant $(P>0.05)$.

$* P<0.05, * * P<0.01, * * * P<0.01$.

$\dagger$ Values fitted to the equation proposed by Ørskov \& McDonald (1979).

$\ddagger$ For details of diets and procedures, see pp. 306-308 and Table 1 .

$\$ 8$ df.

significantly higher in animals eating hay, but the decline later in the day was slower for silage than hay (Fig. 3). With more frequent feeding (Fig. 1(b)) the variation in rumen VFA concentrations was less marked in animals fed on hay, but still ranged from 75 to $105 \mathrm{mmol} / 1$ in those fed on silage. 


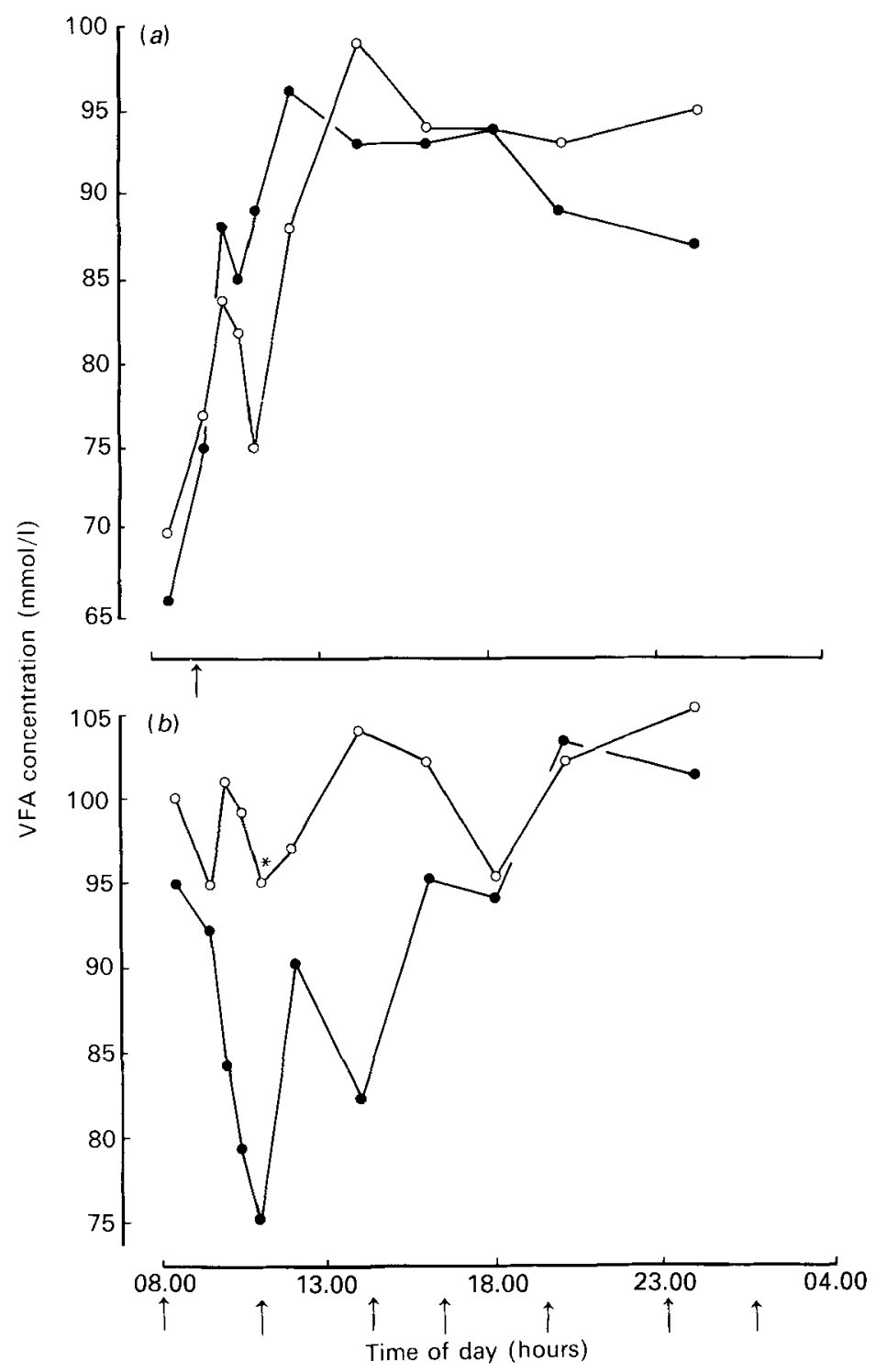

Fig. 1. Diurnal changes in the total concentration of volatile fatty acids (VFA) in rumen fluid from stecrs offered ryegrass (Lolizm perenne cv. Endura) hay (O) or silage (O). (a), Steers offered feed once daily; (b), steers offered feed eight times daily; $\uparrow$, feeding. Mean values were significantly different from those for silage-fed steers: $* P<0.05$. For details of diets and procedures, see p. 306 and Table 1 .

\section{Microbial activity}

There were no significant differences in overall gas production within sampling time or between diets when the steers were fed on hay or silage eight times daily $(13.15 \mathrm{ml}$ and $13.23 \mathrm{ml} / \mathrm{g}$ rumen digesta $\mathrm{DM}$ for hay and silage respectively). However, a significantly $(P<0.05)$ greater microbial activity at the end of a meal in steers fed on silage, compared with hay, was observed when feed was offered once daily (Fig. 4). Thereafter, a decrease in microbial activity occurred, being apparently faster with silage than hay. 


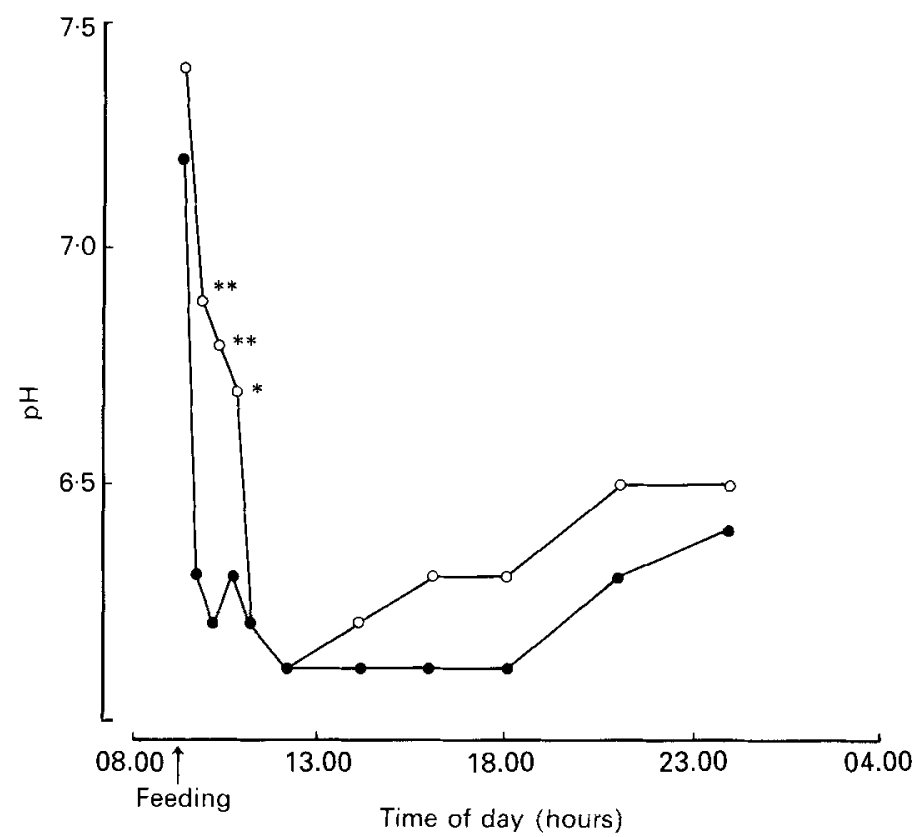

Fig. 2. Diurnal changes in rumen $\mathrm{pH}$ in steers offered ryegrass (Lolium perenne cv. Endura) hay (O) or silage ( once daily. Mean values were significantly different from those for silage-fed steers: ${ }^{*} P<0 \cdot 05$, ${ }^{* *} P<0 \cdot 01$. For details of diets and procedures, see p. 306 and Table 1.

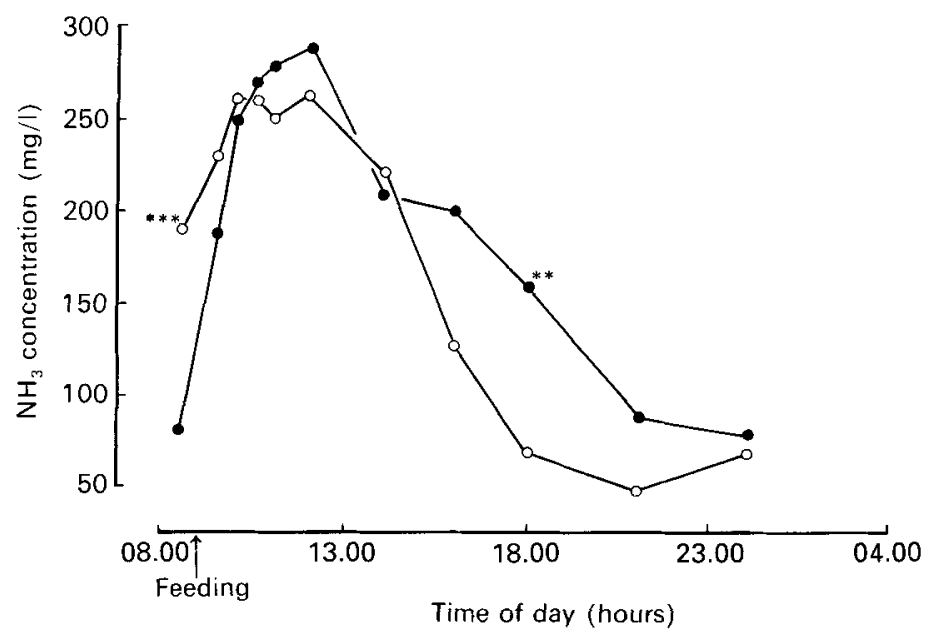

Fig. 3. Diurnal changes in rumen ammonia concentration in steers offered ryegrass (Lolium perenne cv. Endura) hay $(O)$ or silage $(O)$ once daily. Mean values were significantly different from those for silage-fed steers: ${ }^{* *} P<0.0 \mathrm{I},{ }^{* * *} P<0.00 \mathrm{I}$. For details of diets and procedures, see pp. $306-308$ and Table 1 .

\section{Rates of passage}

The volume of liquid in the rumen, as determined by the decline of Co concentration in rumen fluid with time, was higher for hay than silage $(P<0.01)$, and for animals offered feed once compared with eight times daily $(P<0.05)$, as shown in Table 4 . However, the 


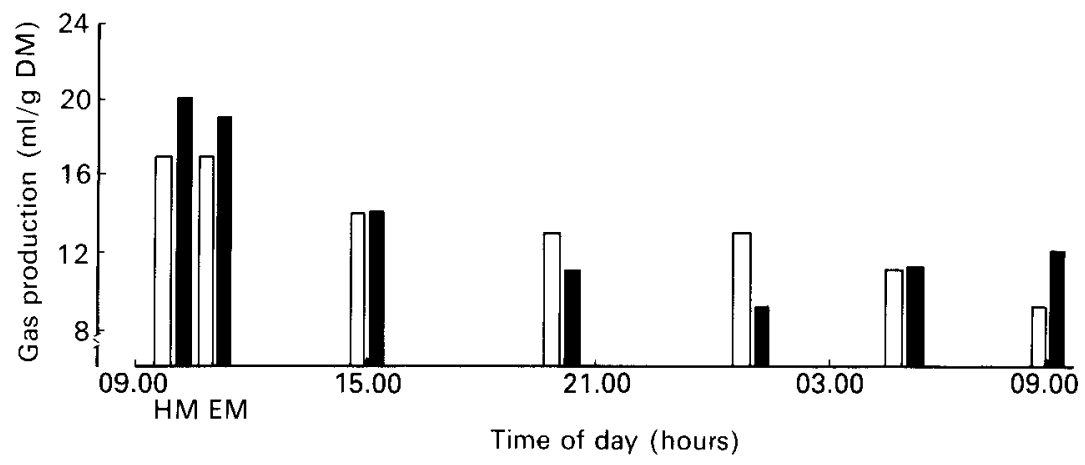

Fig. 4. In vitro gas production from rumen digesta collected at specific times after offering ryegrass (Lolium perenne cv. Endura) hay ( $\square$ ) or silage ( $\mathbf{a}$ ) once daily. DM, dry matter. HM, halfway through the first meal; EM, at end of first meal, For details of diets and procedures see pp. 306-307 and Table 1.

Table 4. Rumen volume $(l)$ and fractional rates of passage of liquid $\left(\mathrm{k}_{1}\right)$ and particulate $\left(\mathrm{k}_{\mathrm{p}}\right)$ material from the rumen of steers offered $20 \mathrm{~g}$ ryegrass (Lolium perenne $c v$. Endura) hay $(H)$ or silage $(S)$ dry matter $/ \mathrm{kg}$ live weight, once $(1 \times)$ or eight times $(8 \times)$ daily

\begin{tabular}{|c|c|c|c|c|c|c|c|}
\hline \multirow{3}{*}{$\begin{array}{l}\text { Treatment } \dagger \ldots \\
\text { Variables }\end{array}$} & \multicolumn{2}{|c|}{$1 \times$} & \multicolumn{2}{|c|}{$8 \times$} & \multirow{3}{*}{ SEM } & \multirow{2}{*}{\multicolumn{2}{|c|}{$\begin{array}{c}\text { Statistical } \\
\text { significance }\end{array}$}} \\
\hline & \multirow[t]{2}{*}{$\mathrm{H}$} & \multirow[t]{2}{*}{$\mathrm{S}$} & \multirow[t]{2}{*}{$\mathrm{H}$} & \multirow[t]{2}{*}{$\mathrm{S}$} & & & \\
\hline & & & & & & $\mathrm{H} v . \mathrm{S}$ & $1 \times$ v. $8 \times$ \\
\hline $\begin{array}{l}\text { Rumen volume } \\
\text { (1) }\end{array}$ & $40 \cdot 0$ & $30 \cdot 2$ & $33 \cdot 9$ & $25 \cdot 1$ & $2 \cdot 17$ & $* *$ & * \\
\hline$k_{1}$ & 0.093 & $0 \cdot 130$ & $0 \cdot 103$ & $0 \cdot 152$ & $0 \cdot 0126$ & $* *$ & NS \\
\hline$k_{p}$ & 0.0342 & $0 \cdot 0283$ & $0 \cdot 0242$ & 0.0255 & 0.00064 & $* *$ & NS \\
\hline & $\begin{array}{l}\text { NS, not s } \\
P<0.0 \\
\text { For det } \\
8 \mathrm{df} .\end{array}$ & $\begin{array}{l}\text { icant }(P \\
P<0.0 \\
\text { of diets }\end{array}$ & $\begin{array}{l}.05), \\
\text { proced }\end{array}$ & see $\mathrm{pp}$. & -308 and & ble 1. & \\
\hline
\end{tabular}

fractional passage rate-constant for passage of liquid out of the rumen was significantly higher for silage than hay and, consequently, there was no difference in outflow rate between these two diets (values not shown).

The fractional passage rates of $\mathrm{Cr}$-mordanted hay and silage out of the rumen were estimated from the decline in $\mathrm{Cr}$ concentration in the rumen and from faecal excretion curves for Cr fitted to the models of Dhanoa et al. (1985) (model 1) and Grovum \& Williams (1973) (model 2). Rate-constants estimated from direct sampling from the rumen $\left(k_{p}\right)$ were significantly higher $(P<0.01)$ for hay than silage, in animals fed once daily, but similar when feed was offered eight times daily (Table 4). Indirect estimation of the fractional passage from the rumen by fitting faecal excretion curves to model 1 and model 2 gave $k_{1}$ values which were similar in magnitude to those determined from rumen samples, but there were no significant differences either between diets or feeding frequencies (Table $5)$. The faster rate-constant $\left(k_{2}\right)$ was greater for silage than hay $(P<0 \cdot 05)$ with values estimated using model 1 but not with model 2 . This faster passage rate was associated with a shorter transit time (TT) $(P<0.05)$ for silage when compared with hay (model 1$)$. The trends in treatment effects were similar with both models but, on this set of data, $k_{2}$ and TT values were consistently higher ( 37 and $29 \%$ respectively) with model 1 . 
Table 5. Passage rates of chromium-mordanted ryegrass (Lolium perenne $c v$. Endura) hav $(H)$ or silage $(S)$, estimated from faecal excretion curves in steers offered $20 \mathrm{~g} \mathrm{H}$ or $S \mathrm{dry}$ matter $/ \mathrm{kg}$ live weight, once $(l \times)$ or eight times $(8 \times)$ daily

\begin{tabular}{|c|c|c|c|c|c|c|c|}
\hline \multirow{3}{*}{$\begin{array}{l}\text { Treatment } \dagger \ldots \\
\text { Variables }\end{array}$} & \multicolumn{2}{|c|}{$1 x$} & \multicolumn{2}{|c|}{$8 \times$} & \multirow{3}{*}{ SEM } & \multirow{2}{*}{\multicolumn{2}{|c|}{$\begin{array}{c}\text { Statistical } \\
\text { significance }\end{array}$}} \\
\hline & \multirow{2}{*}{$\mathrm{H}$} & \multirow{2}{*}{$S$} & \multirow{2}{*}{$H$} & \multirow{2}{*}{$\mathrm{S}$} & & & \\
\hline & & & & & & $\mathrm{H} v . \mathrm{S}$ & $1 \times$ v. $8 \times$ \\
\hline \multicolumn{8}{|l|}{ Model I } \\
\hline$k_{1}$ & 0.028 & 0.027 & 0.028 & 0.029 & 0.0025 & NS & NS \\
\hline$k_{2}$ & $0 \cdot 112$ & 0.138 & $0 \cdot 101$ & $0 \cdot 150$ & 0.0128 & $*$ & NS \\
\hline TT & $22 \cdot 8$ & $21 \cdot 1$ & $23 \cdot 6$ & $20 \cdot 5$ & 1.01 & $*$ & NS \\
\hline TMRT & $67 \cdot 4$ & $68 \cdot 6$ & $72 \cdot 7$ & $62 \cdot 7$ & $3 \cdot 42$ & NS & NS \\
\hline \multicolumn{8}{|l|}{ Model 2} \\
\hline$k_{1}$ & 0.028 & 0.028 & 0.029 & 0.030 & 0.0016 & NS & NS \\
\hline$k_{2}$ & 0.082 & 0.072 & $0 \cdot 067$ & 0.088 & 0.0048 & NS & NS \\
\hline $\mathrm{TT}$ & $16 \cdot 4$ & $15 \cdot 2$ & $16 \cdot 6$ & $14 \cdot 5$ & 0.93 & NS & NS \\
\hline TMRT & $65 \cdot 1$ & $65 \cdot 7$ & $68 \cdot 5$ & $60 \cdot 4$ & $2 \cdot 66$ & NS & NS \\
\hline
\end{tabular}

NS, not significant $(P>0.05) ; k_{1}$, rate-constant of passage (rumen); $k_{2}$, rate-constant of passage (lower gut, model 2); TT, transit time; TMRT, total mean retention time; model 1, Dhanoa et al. (1985); model 2, Grovun \& Williams (1973)

* $P<0.05$

$\dagger$ For details of diets and procedures, see pp. 306-308 and Table 1.

$\ddagger 8 \mathrm{df}$

Table 6. Expt 2. Mean daily ad lib. intake of dry matter of steers eating ryegrass (Lolium perenne cv. Endura) hay or silage†

\begin{tabular}{lcccc}
\hline & & & & \\
& & & $\begin{array}{c}\text { Statistical } \\
\text { significance }\end{array}$ \\
\cline { 3 - 5 } & Hay & Silage & SEM $_{+}^{+}$ & H v. S \\
\hline $\mathrm{kg} / \mathrm{d}$ & $5 \cdot 16$ & 4.53 & 0.089 & $* *$ \\
$\mathrm{~g} / \mathrm{kg}$ live wt per d & 28.6 & 24.4 & 0.42 & $* *$ \\
\hline \hline
\end{tabular}

** $P<0 \cdot 01$

+ For details of diets and procedures, see p. 306 and Table 1.

$+4 \mathrm{df}$.

Voluntary intake in Expt 2

The voluntary intake of DM $(\mathrm{kg} / \mathrm{d})$ was higher $(P<0.01)$ for animals eating hay than for those eating silage (Table 6). This difference was also significant when the DM intake was expressed in $\mathrm{g} / \mathrm{kg} \mathrm{LW}$ per $\mathrm{d}$, being $17 \%$ higher for hay than silage.

\section{DISCUSSION}

The voluntary intake of hay DM by cattle has been established to be generally higher than that of silage made from the same crop at the same time (Murdoch \& Rook, 1963; Waldo et al. 1965; Campling, 1966) and the results from the present study agree with these findings. The voluntary intake of an apparently well-preserved silage was approximately 
$17 \%$ lower $(P<0.01)$ than that of hay made from the same sward of ryegrass harvested on the same day (Table 6). This difference in voluntary intake will be discussed here with reference to the variables related to digestion in, and passage out of, the rumen.

\section{Feed composition}

The silage and hay differed both in physical appearance and in chemical composition. The main physical differences between these forages reflected the high moisture content of the silage so that hay was less succulent, less compact and more brittle than silage. The main effect of ensiling on the chemical composition was to convert most of the WSCHO into fermentation end-products so that the proportion of WSCHO in silage was nine times lower than that in hay. Silage showed lower NDF but higher ADF contents when compared with hay. Similar observations were also made by Uden (1984) who attributed this difference to the breakdown of hemicellulose during ensiling, which may represent a loss of about 10-20\% of the hemicellulose content of silages (Morrison, 1979). According to Dewar et al. (1963) this loss may reflect the action of hemicellulases present in the original herbage, bacterial fermentation, or hydrolysis by organic acids produced during the fermentation.

\section{Digestibility}

Silage is usually made from herbage cut at an earlier stage of maturity than that made into hay and, consequently, has a higher digestibility (Murdoch \& Rook, 1963). However, when both herbages have been cut at the same time, OM and crude fibre digestibilities of hay and silage fed to cattle once daily were found to be similar (Campling, 1966). The present study agrees with this finding as regards the digestibility of the OM of the silage and hay when offered once daily, but the digestibility of NDF was higher and ADF lower for hay than silage (Table 2). Since the hay and silage were harvested from the same sward of ryegrass on the same day, differences in digestibility can be accounted for only by differences in conservation method. Thus, the breakdown of hemicellulose during ensiling may explain the apparent decrease in digestibility of the remaining NDF, while increased ADF digestibility may be due to disruption of natural barriers such as lignin during fermentation in the silo (Van Soest, 1982). Frequency of feeding had no significant effect on digestibility within diets, but with feeding eight times daily DM and OM digestibilities were higher for silage than hay. This may be due to the trend for an increased rate of DM digestion of silage (Table 3 ) in response to more frequent feeding.

\section{Digestion in the rumen}

Both the initial solubilization of DM (a) and its rate of disappearance from Dacron bags $\left(k_{d}\right)$ were higher for silage than hay and there was a lag of $3 \mathrm{~h}$ before initiation of digestion of hay DM (Table 3). These changes can be explained on the basis that ensiled material has a lower DM and has already been subjected to microbial attack, and this leads to more rapid weakening of the leaf structure (see Plates 1 and 2). Akin \& Amos (1975) observed that complete adhesion for degradation is necessary only with less digestible tissues such as bundle sheath and epidermal cells.

This rapid initial solubilization of silage, as recorded from the Dacron bag data, was associated with an increase of $24 \%$ in rumen VFA concentration and, consequently, a sharp fall in $\mathrm{pH}$ (from 7.2 to 6.2 ) within the first hour after feeding. This initial decrease was significantly greater for silage than hay and it is worth noting that this was despite a slower rate of intake of DM for silage compared with hay over this period (Thiago et al. 1992). After $4 \mathrm{~h}$ a steady increase in $\mathrm{pH}$ was observed for hay, but with silage the low $\mathrm{pH}$ was maintained for up to $9 \mathrm{~h}$ after feeding. This correlates with the observations by Thiago et 
al. (1992) that the cattle offered the silage took up to $10 \mathrm{~h}$ to consume the same amount of $\mathrm{DM}$ as was consumed within $2 \mathrm{~h}$ by the animals receiving hay.

More frequent feeding (eight times daily) tended to remove the diurnal variations in $\mathrm{pH}$ and rumen concentrations of VFA and ammonia, although the range of concentration of VFA in cattle offered silage eight times daily was still $30 \mathrm{mmol} / 1$ (Fig. 1(b)). Interestingly, the mean concentration of VFA in animals offered hay eight times daily was higher than the peak concentration in those fed once daily (Fig. 1). This probably reflects the lower rumen volume in these cattle (Table 4) and illustrates the danger of placing too much emphasis on differences in VFA concentrations alone.

The average values for in vitro gas production in cattle offered feed eight times daily (13.15 and $13.23 \mathrm{ml} / \mathrm{g}$ DM for hay and silage respectively) agreed well with the range observed in those offered feed once daily (Fig. 4).

\section{Passage out of the rumen}

The quantity of liquid in the rumen of steers eating hay was higher than in those offered silage, although silage DM was only $21 \%$ compared with $83 \%$ for hay. This difference may reflect the observation that cattle offered hay generally drink more water than those offered silage (Campling, 1966). Fractional rate of passage of liquid from the rumen of steers consuming silage was faster than in those on hay, hence liquid flow from the rumen $(1 / h)$ was similar for both diets.

The fractional rates of passage of solid material appeared to be higher for hay than silage when estimated from curves based on rumen concentrations, in agreement with results reported by Campling (1966) for faecal excretion of stained particles. However, the silage used by Campling (1966) was not precision chopped and, thus, there was a difference in particle size between the hay and the silage which could have confounded the results (e.g. Deswysen \& Ehrlein, 1981). Thus, the results of Lu et al. (1980) and Uden (1984), who found no difference between hay and precision-chopped silage in rates of passage based on interpretation of faecal excretion curves, may be more comparable with the present findings. Indeed, the results in Table 5, based on faecal excretion curves, show no difference between hay and silage. The higher values for hay based on rumen $\mathrm{Cr}$ concentrations may, therefore, be an artifact of the problem of mixing in and sampling from the fuller rumens of the hay-fed cattle (Thiago, 1988). Dietary differences were, however, observed for $k_{2}$ when derived using the Dhanoa et al. (1985) model, being higher for the cattle offered silage. These authors link $k_{2}$ to passage through the caecum, but it is not known why passage through this compartment might differ with conservation method. No dietary difference was observed with the Grovum \& Williams (1973) model.

Feeding frequency did not show any significant effect on fractional passage rates based on faecal excretion of mordanted hay or silage, which is in agreement with results reported by Satter \& Baumgardt (1962) and Goetsch et al. (1982).

In conclusion, the voluntary intake of DM of silage was $17 \%$ lower than that of hay made from the same herbage. This difference could not be explained in terms of differences in overall digestibility or fractional rates of digestion or passage measured at the same DM intake. However, daily intake is the sum of the intake at each individual meal and, hence, a greater understanding of intake control may be achieved by relating the patterns of rumen fermentation measured here, to those for rumen fill, motility and intake as further discussed by Thiago et al. (1992).

L.R.L.T. acknowledges financial support from EMBRAPA (Brazilian Agricultural Research Organisation). The authors would also like to thank Messrs P. England and K. Hill for technical support in the care of the animals, Mrs J. Webb for preparation of the 
scanning electron microscopy plates, and Dr E. Prates and Dr M. K. Theodorou for help with the measurement of gas production. The Institute for Grassland and Animal Production was financed through the AFRC; the work was in part commissioned by the Ministry of Agriculture, Fisheries and Food.

\section{REFERENCES}

Akin, D. E. \& Amos, H. E. (1975). Rumen bacterial degradation of forage cell walls investigated by electron microscopy. Applied Microbiology 29, 692-701.

Campling, R. C. (1966). The intake of hay and silage by cows. Journal of the British Grassland Society $21,41-48$.

Christian, K. R. \& Coup, M. R. (1954). Measurement of feed intake by grazing cattle and sheep. VI. The determination of chromic oxide in faeces. New Zealand Journal of Science and Technology A 36, 328-330.

Clancy, M., Wangsness, P. J. \& Baumgardt, B. R. (1977). Effect of silage extract on voluntary intake, rumen fluid constituents and rumen motility. Journal of Dairy Science 60, $580-590$.

Demarquilly, C. (1973). Chemical composition, fermentation characteristics, digestibility and voluntary intake of forage silages: changes compared to the initial green forage. Annales de Zootechnie 22, 1-35.

Deswysen, A. G. \& Ehrlein, H. J. (1981). Silage intake, rumination and pseudo-rumination activity in sheep studied by radiography and jaw movement recordings. British Journal of Nutrition 46, 327-335.

Dewar, W. A. \& McDonald, P. (1961). Determination of dry matter in silage by distillation with toluene. Journal of the Science of Food and Agriculture 12, 790-795.

Dewar, W. A., McDonald, P. \& Whittenbury, R. (1963). The hydrolysis of grass hemicelluloses during ensilage. Journal of the Science of Food and Agriculture 14, 411-417.

Dhanoa, M. S. (1988). On the analysis of dacron bag data for low degradability feeds. Grass and Forage Science 43, $441-444$

Dhanoa, M. S., Siddons, R. C., France, J. \& Gale, D. L. (1985), A multicompartmental model to describe marker excretion patterns in ruminant faeces. British Joumal of Nutrition 53, 663-671.

Freer, M. \& Campling, R. C. (1963). Factors aflecting the voluntary intake of food by cows. 5. The relationship between the voluntary intake of food, the amount of digesta in the reticulorumen and the rate of disappearance of digesta from the alimentary tract with diets of hay, dried grass or concentrates. British Journal of Nutrition 17, $79-88$.

Gehrke, G. W., Kaiser, F. E. \& Ussary, J. P. (1968). Automated spectrophotometric method for nitrogen in fertilizers. Journal of the Association of Official Analytical Chemists 51, 200-211.

GENSTAT (1977). A General Statistical Program. Harpenden, Herts: Rothamsted Experimental Station.

Goetsch, A. L., Galyean, M. L. \& Cardenas, M. (1982). Effects of frequency of feeding on passage of a particulate marker as determined by rumen or faecal sampling. Journal of Animal Science 55, Suppl., 426 Abstr.

Grovum, W. L. \& Williams, V. J. (1973). Rate of passage of digesta in sheep. 4. Passage of marker through the alimentary tract and the biological relevance of rate constants derived from the changes in concentration of marker in faeces. British Journal of Nutrition 30, 313-329.

Lu, C. D., Jorgensen, N. A. \& Barrington, G. P. (1980). Intake, digestibility, and rate of passage of silages and hays from wet fractionation of alfalfa. Journal of Dairy Science 63, 205 I--2059.

McDonald, I. (1981). A revised model for the estimation of protein degradability in rumen. Journal of Agricultural Science, Cambridge 96, 251-252.

McDonald, P. \& Edwards, R. A. (1976). The influence of conservation methods on digestion and utilization of forages by ruminants. Proceedings of the Nutrition Society 35, 201-211.

McDonald, P. \& Henderson, A. R. (1964). The determination of water-soluble carbohydrates in grass. Journal of the Science of Food and Agriculture 15, 375-379.

Morrison, I. M. (1979). Changes in the cell wall components of laboratory silages and the effect of various additives on these changes. Journal of Agricultural Science, Cambridge 93, 581-586.

Murdoch, J. C. \& Rook, J. A. F. (1963). A comparison of hay and silage for milk production. Journal of Dairy Research 30, 39I-397.

Ørskov, E. R. \& McDonald, I. (1979). The estimation of protein degradability from incubation measurements weighted according to rate of passage. Journal of Agricultural Science, Cambridge 92, 499 503.

Prates, E. R., Thiago, L. R. S., Gill, M. \& Theodorou, M. K. (1986). The effect of conservation method and frequency of feeding on rumen microbial activity. Proceedings of the Nutrition Society 45, 95A.

Ross, G. J.S. (1980). MLP: Maximum Likelihood Program. Harpenden, Herts: Rothamsted Experimental Station.

Satter, L. D. \& Baumgardt, B. R. (1962). Changes in digestive physiology of the bovine associated with various feeding frequencies. Journal of Animal Science 21, 897-900.

Sullivan, J. T. (1973). Drying and storing herbage as hay. In Chemistry and Biochemistry of Herbage, vol. 3 , pp. 1-31 [G. W. Butler and R. W. Bailey, editors]. London: Academic Press.

Thiago, L. R. L. (1988). Voluntary intake of forages by ruminants : factors related to eating behaviour and rumen fill. PhD Thesis, University of Reading. 
Thiago, L. R. L., Gill, M. \& Sissons, J. W. (1992). Studies of method of conserving grass herbage and frequency of feeding in cattle. 2. Eating behaviour, rumen motility and rumen fill. British Journal of Nutrition 67: 319.336.

Uden, P. (1984). Digestibility and digesta retention in dairy cows receiving hay or silage at varying concentrate levels. Animal Feed Science and Technology 11, 279-291.

Uden, P., Colucci, P. E. \& Van Soest, P. J. (1980). Investigation of chromium, cerium and cobalt as markers in digesta. Rate of passage studies. Journal of the Science of Food and Agriculture 31, 625-632.

Van Soest, P. J. (1963). Use of detergents in the analysis of fibrous feeds. II. A rapid method for the determination of fiber and lignin. Joumal of the Association of Official Analytical Chemists 46, 829-835.

Van Soest, P. J. (1982). Nutritional Ecology of the Ruminant. Corvallis, Oregon: O \& B Books Inc,

Van Soest, P. J. \& Robertson, J. B. (1980). Systems of analysis for evaluating fibrous feeds. In Standardisation of Analytical Methodology for Feeds, pp. 49-60 [W. J. Pigden, C. C. Balch and M. Graham, editors]. Ottawa: International Development Research Centre.

Van Soest, P. J. \& Wine, R. H. (1967). Use of detergents in the analysis of fibrous feeds. IV. Determination of plant cell wall constituents. Joumal of the Association of Official Analytical Chemists 50, 50-55.

Waldo, D. R., Miller, R. W., Okamoto, M. \& Moore, L. A. (1965). Ruminant utilization of silage in relation to hay, pellets, and hay plus grain. I. Composition, digestion, nitrogen balance, intake, and growth. Journal of Dairy Science 48, 910.916.

Warner, A. C. I. \& Stacy, B. D. (1968). The fate of water in the rumen. 1. A critical appraisal of the use of soluble markers. British Journal of Nutrition 22, 369-387. 


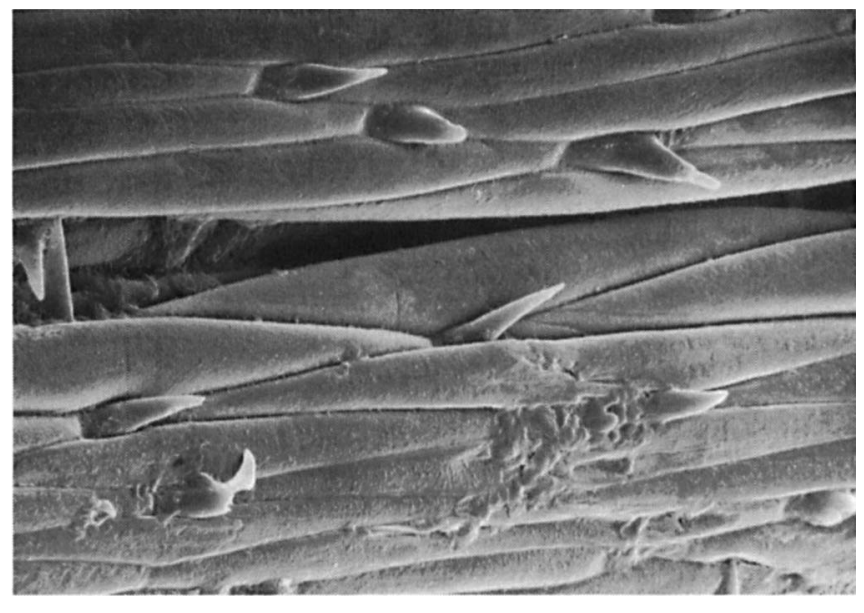

$0.1 \mathrm{~mm}$

Plate 1. Cryo-scanning electron micrograph of leaf surface of ryegrass (Lolium perenne cv. Endura) hay after incubation in Dacron bag for $5 \mathrm{~h}$ in rumen of cattle.

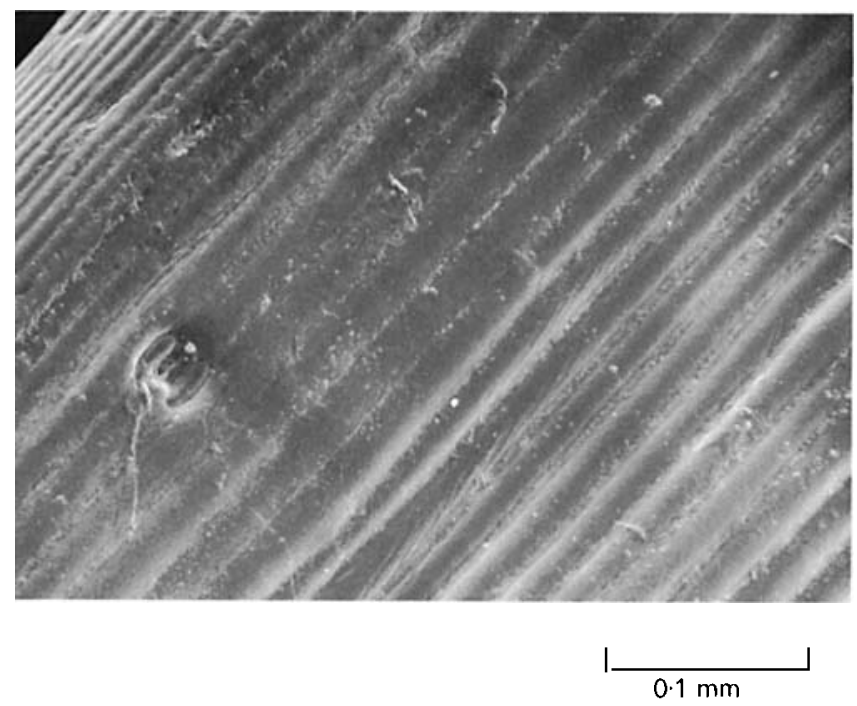

Plate 2. Cryo-scanning electron micrograph of leaf surface of ryegrass (Lolium perenne cv. Endura) silage after incubation in Dacron bag for $5 \mathrm{~h}$ in rumen of cattle. 